\title{
IMPACT OF DIFFERENT WATER MANAGEMENT SCENARIOS ON CORN WATER USE EFFICIENCY
}

\author{
A. K. Singh, C. A. Madramootoo, D. L. Smith
}

\begin{abstract}
This study investigated the water balance, crop yield, and water use efficiency (WUE) of a water table management system compared to a conventional drainage system at three nitrogen levels. A two-year field study was conducted using three blocks; each block was composed of two water management treatments: controlled drainage with subirrigation (CD-SI) and conventional or free drainage (FD). The water table depth was maintained at $60 \mathrm{~cm}$ below the soil surface in the CD-SI plots. Three nitrogen treatments (low, medium, and high) were applied in strips across all blocks. The seasonal water balance indicated surplus water conditions in the CD-SI plots, while the FD plots had deficit conditions. In 2008 and 2009, the corn grain WUE for the FD plots was 2.49 and $2.46 \mathrm{~kg} \mathrm{~m}^{-3}$ respectively. The corn grain WUE for the CD-SI plots was 2.43 and $2.26 \mathrm{~kg} \mathrm{~m}^{-3}$ in 2008 and 2009, respectively. The WUE of corn grain responded to the water treatments $(p<0.05)$ in 2009 but not in 2008. In 2009, at low and high nitrogen levels, the water management treatments demonstrated significant differences $(p<0.05)$ in grain yields. However, water management demonstrated no significant effect $(p>0.05)$ on grain yields at the normal nitrogen level. Furthermore, the two water treatments had no effect on the aboveground dry biomass yields in both years.
\end{abstract}

Keywords. Controlled drainage, Corn (Zea mays), Subirrigation, Water balance, Water table management, Water use efficiency.

$\mathrm{I}$ rrigated agriculture accounts for nearly $70 \%$ of total fresh water use worldwide, representing the largest use of fresh water (Siebert et al., 2007). In the U.S., irrigated agriculture accounts for $58 \%$ and $42 \%$ of total surface and groundwater use, respectively (USGS, 2005). Although fresh water is considered a renewable resource, the fresh water available for irrigation is steadily decreasing globally. In North Gujarat, India, water tables are falling by $6 \mathrm{~m}$ per year due to higher utilization compared to the rate of aquifer recharge (Brown, 2006). In three major U.S. grain-producing areas (Texas, Oklahoma, and Kansas), the water table has dropped by more than $30 \mathrm{~m}$ (Brown, 2006). One way to address this decline in irrigation water availability is to enhance water use efficiency (WUE) in irrigated agriculture, i.e., increase the crop output per unit of water, reduce loss of water to unusable sinks (e.g., in the unsaturated vadose zone, the ocean, or salt sinks), reduce water quality degradation, and reallocate water to higher-priority uses (Howell, 2001).

Corn is one of the world's most important cereal crops. North America produces approximately $44 \%$ of the world's

Submitted for review in November 2012 as manuscript number SW 10005; approved for publication by the Soil \& Water Division of ASABE in July 2014.

The authors are Ajay K. Singh, Research Associate, and Chandra A. Madramootoo, ASABE Fellow, Professor, Department of Bioresource Engineering, and Donald L. Smith, Professor, Department of Plant Science, McGill University, Montreal, Quebec, Canada. Corresponding author: Ajay Singh, Department of Bioresource Engineering, McGill University, 21,111 Lakeshore Road, Ste Anne de Bellevue, Montreal, QC, Canada H9X 3V9; phone: 514-398-7837; e-mail: ajay.singh@mail. mcgill.ca. corn (FAOSTAT, 2009). In 2009, corn was harvested from 158 million ha of land that produced about 819 million $\mathrm{Mg}$ grain worldwide. In the same year, Canada harvested 1.14 million ha of corn with a production of 9.56 million Mg (FAOSTAT, 2009). Grain corn is the second most widely grown crop in the province of Quebec, Canada, with a peak cropped area of 450,000 ha in 2007-2008 (Statistics Canada, 2011). More judicious use of water and fertilizer would increase the yields and land productivity associated with corn production.

In humid regions, surface and subsurface drainage is necessary to increase agricultural production on many flat lands. Approximately, 8 million ha of land in Canada are drained, mainly by surface drainage. Tile drains have been installed extensively in the U.S. and Canada to drain excess soil water from agricultural lands and to mitigate water logging. Subsurface drainage has been implemented on over 2.5 million ha of agricultural land in the provinces of Ontario and Quebec (ICID, 2011). In Quebec, over 735,000 ha of farmland are drained by subsurface drainage (Gollamudi, 2006). A large proportion of this subsurface drained land is used for grain corn production.

Subsurface drainage removes gravitational water, improves field trafficability, and increases crop yields (King, 1918). In coarse-textured soils with subsurface drainage, the water table can be rapidly lowered below the level of the tile drains. The resulting effect is overdrainage, which can lead to drought stress during drier summer periods (Skaggs, 1977). This may reduce crop yields. In this situation, farmers can close the drains during dry periods to potentially retain the moisture in the field from timely rains (Stampfli and Madramootoo, 2006). Subirrigation in con- 
junction with controlled drainage (CD-SI), achieved by maintaining a desirable water table depth, allows more control over soil moisture conditions and provides optimal water conditions for growth. During periods of water deficit, water is provided to the crop from an external source via the drainage system. This reduces drought stress and provides the crop with supplemental water for adequate growth. Conversely, when precipitation exceeds the amount of water required by the crop, subirrigation is stopped and excess water is drained from the field.

Drained lands are some of the most productive in the world (Wright and Sands, 2001). Madramootoo (1990) reported increased soil water storage capacity and less damage to the soil structure with CD-SI systems. Hundal et al. (1976) reported that CD-SI systems improved soil physical properties. Other benefits of controlled drainage with subirrigation include decreased peak flow rates and outflow volumes for drainage under certain conditions and a substantial reduction of nitrate concentrations as compared to conventional drainage outflows (Mejia and Madramootoo, 1998; Skaggs et al., 1995; Madramootoo et al., 1992), and increased crop yield (Zhao et al., 2000; Madramootoo et al., 2001, Busman and Sands, 2012; Stampfli and Madramootoo, 2006).

Although Canada is a water-rich country, the future provision of this resource should not be taken for granted (Mehdi et al., 2006). Although climate change projections may be laced with uncertainties, adaptation is necessary to ensure a sufficient water supply for economic development, the environment, and recreation, and more importantly to preserve peace between user groups (Mehdi et al., 2006). By the 2090s, regions such as Canada's southern prairies could experience serious summer deficiencies in soil moisture (Hengeveld, 2000), hence the need for efficient use of water resources.

There have been few studies on the interaction effects of water table management and different nitrogen rates on water use efficiency (WUE) in humid regions. Previous researchers have investigated the nitrogen $(\mathrm{N})$ uptake (Zhou et al., 2000), the effect of different water table depths on corn and soybean yields (Mejia et al., 2000), water quality (Madramootoo et al. 2001), and subirrigation water use efficiency at one $\mathrm{N}$ application rate (Stampfli and Madramootoo, 2006) in Coteau-du-Lac, southern Quebec. The present study investigated the WUE, water balance, and corn yields for various water management scenarios over a range of nitrogen levels. There have been no previous studies on the water balance at the study site.

\section{Materials ANd Methods \\ DESCRIPTION OF THE STUDY AREA}

The experimental field work was conducted on a 4.2 ha field $\left(45.32^{\circ} \mathrm{N}, 74.17^{\circ} \mathrm{W}\right)$ in Coteau-du-Lac, Quebec, Canada in 2008 and 2009. The study area lies in the St. Lawrence lowlands, approximately $60 \mathrm{~km}$ west of Montreal, in Soulanges County. The soil at the site is a Soulanges very fine sandy loam (Lajoie and Stobbes, 1951). It has a mean depth of 50 to $90 \mathrm{~cm}$ and overlays clay deposits from the Champlain Sea. The field has a flat topography, with an average slope of less than $0.5 \%$ (Kaluli et al., 1999).

\section{Experimental Design AND Agronomy Practices}

The experimental field was divided into three blocks (fig. 1). A strip split-plot design was used to study the effects of water table management and nitrogen treatments on corn. The two water management treatments (main plots) were contained in each block and ran along the direction of the drainage pipes (north-south). The three nitrogen treatments were applied orthogonally in strips over the main plots across the entire field. Each strip was $18 \mathrm{~m}$ wide. The two water management treatments compared in this study were free drainage (FD) and CD-SI (also referred to as subirrigation plots). The three nitrogen treatments were low $\mathrm{N}$, normal N, and high $\mathrm{N}$. Thus, each block was comprised of six plots of $18 \mathrm{~m} \times 30 \mathrm{~m}$. Tables 1 and 2 list the water and nitrogen treatments, respectively.

The water treatment plots were isolated from each other by vertical plastic curtains installed to a depth of $1.5 \mathrm{~m}$ to prevent lateral seepage (Tait et al., 1995). The water table

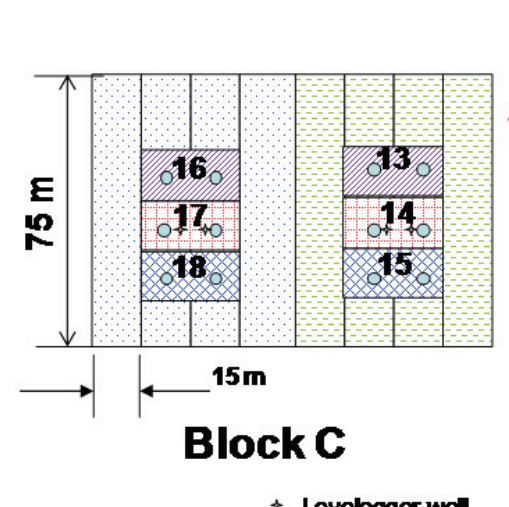

+ Levelogger wel

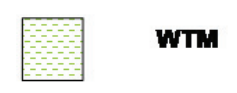

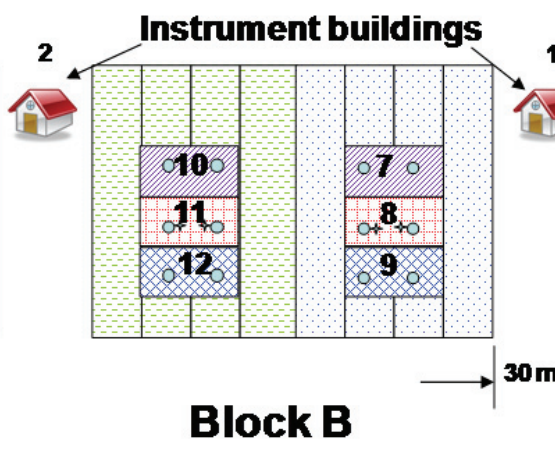

- Observation wel

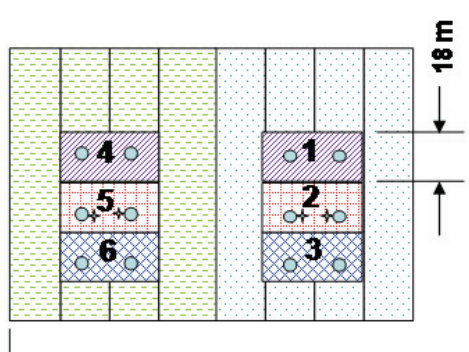

Block A
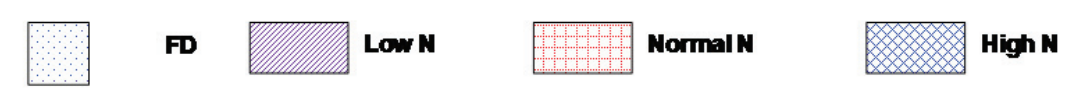

Figure 1. Experimental layout. The numbers 1 to 18 denote plots. 
Table 1. Average water table depth $(\mathrm{m})$ from ground surface of two water table management treatments during the growing season (May to September). ${ }^{[\mathrm{a}]}$

\begin{tabular}{|c|c|c|c|c|}
\hline \multirow[b]{2}{*}{ Year } & \multicolumn{2}{|c|}{ Mean } & \multicolumn{2}{|c|}{ SD } \\
\hline & FD & CD-SI & FD & CD-SI \\
\hline 2008 & 1.04 & 0.60 & 0.28 & 0.27 \\
\hline 2009 & 1.13 & 0.75 & 0.16 & 0.15 \\
\hline
\end{tabular}

Table 2. Yearly nitrogen application rates $\left(\mathrm{kg} \mathrm{ha}^{-1}\right)$ applied to corn.

\begin{tabular}{cccc}
\hline Year & Low N & Normal N & High N \\
\hline 2008 & 131 & 186 & 277 \\
2009 & 112 & 179 & 246 \\
\hline
\end{tabular}

depth was set at $0.60 \mathrm{~m}$ and $0.75 \mathrm{~m}$ below the ground for CD-SI plots in 2008 and 2009, respectively (table 1). Buffer plots separated the water treatment plots. There were 24 rows of corn in each nitrogen subplot. Five rows along the edges in each of these plots were considered buffer rows. Measurements and samplings excluded these rows. The drains were installed at a depth of $1.0 \mathrm{~m}$ below the ground surface in the center of each main plot. The drains discharged into two buildings located on the north side of the field (fig. 1).

In 2008, corn cultivar Mycogen 2R426 was planted on 4 May with a seeding rate of 89,000 plants $\mathrm{ha}^{-1}$. In 2009, the producer planted corn variety Pioneer $38 \mathrm{~N} 8 \mathrm{~T}$ on 3 May with a seeding rate of 85,000 plants ha ${ }^{-1}$. In 2008, the desired nitrogen rate was achieved (table 2 ) by applying nitrogen in three applications. In 2009, the desired nitrogen rate was achieved through two applications. The three nitrogen fertilizer rates (high, medium, low) were selected based on previous research at the site. The high $\mathrm{N}$ rate, varying from 246 to $277 \mathrm{~kg} \mathrm{~N}^{-1}$, was based on the findings of Zhou et al. (2000). The normal N rate of 179 to $186 \mathrm{~kg}$ $\mathrm{ha}^{-1}$ is the rate that the farmer generally applies. The low $\mathrm{N}$ rate $\left(112\right.$ to $\left.131 \mathrm{~kg} \mathrm{ha}^{-1}\right)$ was selected in order to achieve a contrast in $\mathrm{N}$ applications.

\section{MONITORING OF WATER TABLE DEPTH}

Water table depth was measured every 7 to 10 days using observation wells installed in each plot. The pipes were $2.54 \mathrm{~cm}$ diameter PVC pipes with $2 \mathrm{~mm}$ holes along their whole length, located approximately $5 \mathrm{~cm}$ apart, and wrapped in geotextile to prevent clogging with fine soil particles. There were two observation wells in each plot. In the "normal N" plots, leveloggers (model 3001, Solinst Canada, Ltd., Georgetown, Ontario) were also installed in monitoring wells, which recorded the water table depth at 15 min intervals. In order to compute the actual water table depths, it was necessary to compensate for atmospheric pressure, which was measured by separate leveloggers installed close to the ground surface in each block. The water table measurements from the observation wells were used to verify the levelogger data (fig. 2).

\section{SOIL WATER BALANCE}

Following the approach of Skaggs et al. (2010), the soil water balance is expressed as follows:

$$
I+P=\mathrm{ET}_{c}+R O+D P+D \pm \Delta S W-U F
$$

where $I$ is irrigation, $P$ is precipitation, $\mathrm{ET}_{c}$ is crop evapotranspiration, $R O$ is surface runoff, $D P$ is deep percolation, $D$ is drainage, $\Delta S W$ is change in the soil water storage, and $U F$ is upward flux. All units are in mm. A water balance was done for 0 to $100 \mathrm{~cm}$ and for 0 to $60 \mathrm{~cm}$ of the soil profile in the FD and CD-SI plots, respectively. The upward water movement due to upward flux is accounted for by measuring the change in soil moisture storage at different depths.

No surface runoff was observed; hence, runoff was assumed to be negligible (Stampfli and Madramootoo, 2006). Based on work by Kaluli et al. (1999) at the same site, deep percolation was negligible and assumed to be zero in the above equation. Therefore, equation 1 was simplified as shown in equation 2 :

$$
I+P=\mathrm{ET}_{c}+D \pm \Delta S W-U F
$$

Subsurface irrigation was achieved by pumping water from a well into the drainage pipes situated in buildings 1 and 2 (fig. 1). A flowmeter in building 1 measured the irrigation water supplied to block $\mathrm{A}$, while another flowmeter in building 2 measured the irrigation water supplied to blocks B and C. Since there were not individual flowmeters for each plot, the total water supplied to each block was assumed to be equally distributed to each plot. Subirrigation for the CD-SI plots commenced on 25 June and

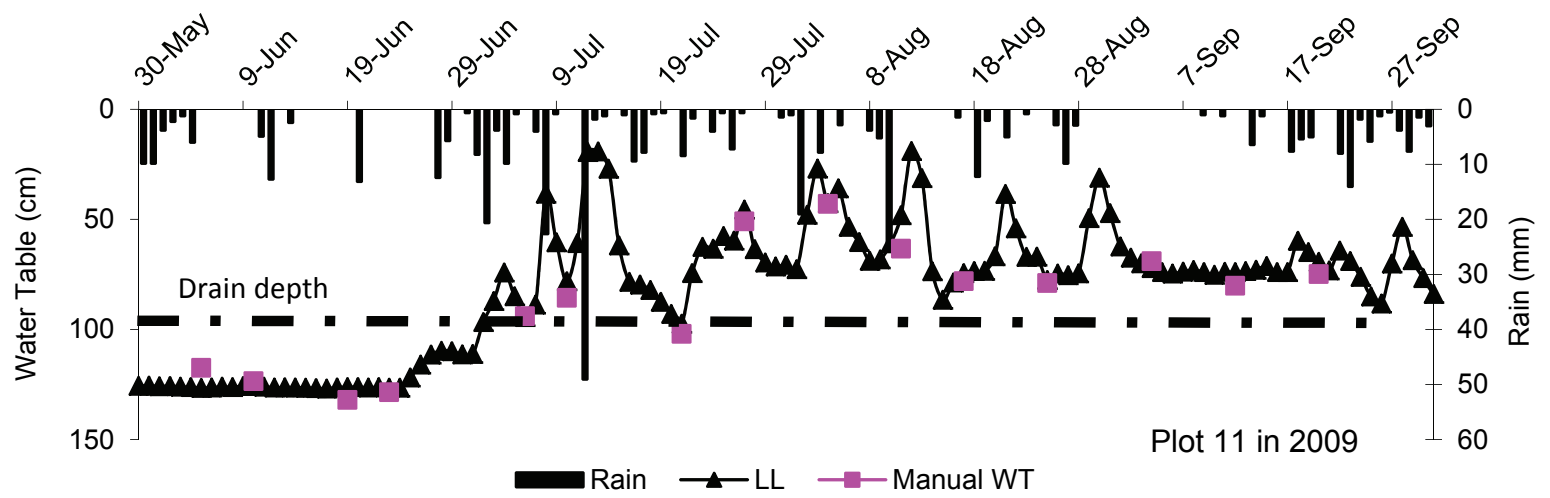

Figure 2. Comparison of water table depth measurements using observation wells and automatic leveloggers $(\mathrm{LL}=$ water table depth measured by leveloggers, and Manual WT = water table depth measured in observation wells). 
23 June in 2008 and 2009, respectively. For each subirrigation plot, a water table control chamber regulated the flow of water into and out of the plots (Tait et al., 1995). If the water table depth was greater than $60 \mathrm{~cm}$, water flowed into the plots, and vice versa. The irrigation pump was started manually and then turned off manually when the water table moved close to the ground surface $(<30 \mathrm{~cm})$. During times of high precipitation, valves were open to drain surplus water and to lower the water table to the desired depth for the CD-SI plots. When the water table reached the desired depth, the drainage valves were closed and the irrigation pump was started. In 2008, subirrigation was stopped on 9 September and the drainage pipes were opened on 15 September. In 2009, the irrigation pump was turned off and the drainage pipes were opened on 20 September to enable crop harvesting.

Crop evapotranspiration $\left(\mathrm{ET}_{c}\right)$ was calculated by adjusting the FAO Penman-Monteith equation with crop coefficients (Allen et al., 1998):

$$
\begin{gathered}
\mathrm{ET}_{r}=\frac{0.408 \Delta\left(R_{n}-G\right)+\gamma \frac{900}{T+273} u_{2}\left(e_{s}-e_{a}\right)}{\Delta+\gamma\left(1+0.34 u_{2}\right)} \\
\mathrm{ET}_{c}=K_{c} \mathrm{ET}_{r}
\end{gathered}
$$

where $\mathrm{ET}_{r}$ is reference evapotranspiration $\left(\mathrm{mm} \mathrm{d}^{-1}\right), R_{n}$ is net radiation at the crop surface ( $\left.\mathrm{MJ} \mathrm{m}^{-2} \mathrm{~d}^{-1}\right), G$ is soil heat flux density $\left(\mathrm{MJ} \mathrm{m}^{-2} \mathrm{~d}^{-1}\right), T$ is mean daily air temperature at $2 \mathrm{~m}$ height $\left({ }^{\circ} \mathrm{C}\right), u_{2}$ is wind speed at $2 \mathrm{~m}$ height $\left(\mathrm{m} \mathrm{s}^{-1}\right), e_{s}$ is saturation vapor pressure $(\mathrm{kPa}), e_{a}$ is actual vapor pressure $(\mathrm{kPa}), e_{s}-e_{a}$ is saturation vapor pressure deficit $(\mathrm{kPa}), \Delta$ is the slope of the vapor pressure curve $\left(\mathrm{kPa}^{\circ} \mathrm{C}^{-1}\right), \gamma$ is the psychrometric constant $\left(\mathrm{kPa}^{\circ} \mathrm{C}^{-1}\right), K_{c}$ is the crop coefficient, and $\mathrm{ET}_{c}$ is actual evapotranspiration. Reference or potential evapotranspiration could be less or more than the standard conditions (eq. 3); hence, it was adjusted to actual evapotranspiration with equation 4 . Previous research at this site indicated that maintaining the water table at $60 \mathrm{~cm}$ could meet crop ET requirements (Madramootoo et al., 1993).

The crop coefficient used in equation 4 was adjusted for variations in crop growth during the growing seasons, based on daily climate data, using the following equations (Allen et al., 1998):

$$
\begin{aligned}
K_{c \text {-mid }}= & K_{c \text {-mid(FAO })}+\left[0.04+\left(u_{2}-2\right)\right. \\
& \left.-0.004\left(\mathrm{RH}_{\text {min }}-45\right)\right]\left(\frac{h}{3}\right)^{0.3} \\
K_{c \text {-end }}= & K_{c \text {-end(FAO })}+\left[0.04+\left(u_{2}-2\right)\right. \\
- & \left.0.004\left(\mathrm{RH}_{\text {min }}-45\right)\right]\left(\frac{h}{3}\right)^{0.3}
\end{aligned}
$$

where $K_{c \text {-mid }}$ is the crop coefficient for the mid-season growth stage, $K_{c \text {-mid(FAO) }}$ is the mid-season crop coefficient value in table 12 of Allen et al. (1998), $u_{2}$ is the mean value for daily wind speed at $2 \mathrm{~m}$ height during the mid-season stage $\left(\mathrm{m} \mathrm{s}^{-1}\right), \mathrm{RH}_{\min }$ is mean value for minimum relative humidity during the mid-season stage (\%), $h$ is the mean plant height during the mid-season stage (m), $K_{c \text {-end }}$ is crop coefficient for the end-of-season stage, and $K_{c \text {-end(FAO) }}$ is the end-of-season crop coefficient value in table 12 of Allen et al. (1998).

An on-site weather station provided weather variables such as temperature, humidity, wind speed, longwave radiation, and shortwave radiation for equations 3, 5, and 6 . Weather data were recorded hourly and were comparable to data available from the Environment Canada weather station at Coteau-du-Lac (Station ID 7011947) located $500 \mathrm{~m}$ from the experimental site. Precipitation data were taken from the Environment Canada weather station at Coteaudu-Lac due to its better data availability.

Drainage flows were measured using tipping buckets in buildings 1 and 2 . The tipping buckets were calibrated and connected to a datalogger, which recorded the data continuously (Tait et al., 1995). Changes in soil profile moisture were measured with two sets of sensors. Watermark soil moisture sensors (model 6450, Spectrum Technologies, Inc., Plainfield, Ill.) and Theta probes (ML2x, Delta-T Devices, Ltd., Cambridge, U.K.) were installed at depths of 15 and $45 \mathrm{~cm}$, respectively, below the surface of each subplot. Data obtained from the Watermark sensors were in pressure units $(\mathrm{kPa})$ and were converted to percentage moisture content using soil moisture characteristic curves. Soil moisture characteristic curves were obtained for various soil layers with a pressure plate apparatus (model 1500 and 1600 pressure extractors, Soilmoisture Equipment Corp., Santa Barbara, Cal.) in the laboratory.

Upward flux was estimated using the Rosetta utility in DRAINMOD 6.1. The soil preparation program includes a routine that calculates the maximum water table depth that will support a given upward flux value. The program inputs are average depth of the root zone, depth of each layer, maximum tension in the root zone when it is dry, and each layer's unsaturated conductivity versus tension relationship. Upward flux was obtained from the Rosetta output based on the field-measured water table depths.

\section{WATER USE EFFICIENCY (WUE)}

In this study, WUE was determined using several methods. First, WUE was defined as the ratio of grain yield $(\mathrm{kg})$ to crop evapotranspiration $\left(\mathrm{m}^{3}\right)$ and denoted as crop water use efficiency $\left(\mathrm{WUE}_{\mathrm{ET}}\right)$ :

$$
\mathrm{WUE}_{\mathrm{ET}}\left(\mathrm{kg} \mathrm{m}^{-3}\right)=\frac{Y(\mathrm{~kg})}{\mathrm{ET}_{c}\left(\mathrm{~m}^{3}\right)}
$$

where $\mathrm{WUE}_{\mathrm{ET}}$ is the crop water use efficiency, $Y$ is the yield, and $\mathrm{ET}_{c}$ is the crop evapotranspiration.

WUE was also defined as the ratio of grain yield $(\mathrm{kg})$ to the amount of water $\left(\mathrm{m}^{3}\right)$ supplied through subirrigation, known as subirrigation water use efficiency (Stampfli and Madramootoo, 2006), and denoted as SWUE $_{\text {SI }}$ (eq. 8). There was no $\mathrm{SWUE}_{\mathrm{SI}}$ calculation for the FD plots because subirrigation water was not applied to these plots. However, in humid areas where there is frequent rainfall during the season, $\mathrm{SWUE}_{\mathrm{SI}}$ can be very high, given that grain yields would be due to both irrigation and precipitation. In 
these situations, SWUE is defined by equation 9 (Pablo et al., 2007). Bos (1980) determined the irrigation water use efficiency by differentiating the yield obtained for dry land or rainfed crops and the yields for irrigated land, as shown in equation 10 :

$$
\begin{gathered}
\mathrm{SWUE}_{\mathrm{SI}}=\frac{Y(\mathrm{~kg})}{\text { Irrigation water supplied }\left(\mathrm{m}^{3}\right)} \\
\text { SWUE }_{\mathrm{TW}}=\frac{Y(\mathrm{~kg})}{\text { Total water supplied (rain+irrig., } \left.\mathrm{m}^{3}\right)} \\
\mathrm{SWUE}_{\mathrm{TSI}}=\frac{Y_{\mathrm{FD}}-Y_{\mathrm{CD}-\mathrm{SI}}(\mathrm{kg})}{\text { Irrigation water supplied }\left(\mathrm{m}^{3}\right)}
\end{gathered}
$$

\section{Crop Yield AND ABoveground Biomass SAMPLiNG}

The matured corn grain and aboveground biomass yield were measured at the time of harvest. Each plot was divided into four sections. Leaving rows at the edges as a buffer, five consecutive plants in each section were randomly selected in a row. Thus, 20 plants were collected from each plot. In 2008 and 2009, the samples were collected on 12 and 14 October, respectively. Cobs were separated in the field and placed in paper bags. Stalks were weighed and chopped at an off-site location the following day. Biomass subsamples for each plot were collected, weighed again, and dried in an electric oven (model WO-4542, P.M. Wright Electrical Co., Montreal, Quebec, Canada) at $70^{\circ} \mathrm{C}$ for $48 \mathrm{~h}$. Harvested cobs were oven-dried in the same way. The dried biomass and the mass of dry grain were transformed into crop yields in $\mathrm{Mg} \mathrm{ha}^{-1}$ to allow for comparison with other published data.

\section{Statistical AnALYSES}

The model for a strip split-plot design is shown below (Montgomery, 2009):

$$
\begin{aligned}
Y_{i j k} & =\mu+\rho_{i}+\alpha_{j}+(\rho \alpha)_{i j}+\beta_{k}+(\rho \beta)_{i k} \\
& +(\alpha \beta)_{j k}+\varepsilon_{i j k}
\end{aligned}
$$

where $Y_{i j k}$ is the observation corresponding to the $k$ th level of factor A (water treatment), the $j$ th level of factor B (nitrogen treatment), and the $i$ th replication; $\mu$ is the population mean; $\rho_{i}$ is the $i$ th block effect; $\alpha_{j}$ is the effect of the $j$ th level of factor $\mathrm{A} ; \beta_{k}$ is the effect of the $k$ th level of factor $\mathrm{B}$; and $(\alpha \beta)_{j k}$ is the interaction between the $j$ th level of factor $\mathrm{A}$ and the $k$ th level of factor $\mathrm{B}$. The error components, $(\rho \alpha)_{i j}$, $(\rho \beta)_{i k}$, and $\varepsilon_{i j k}$, were statistically verified (SAS, 2010) to be independently and normally distributed with a mean of zero and respective variances $\sigma_{a}^{2}, \sigma_{b}^{2}$, and $\sigma_{\varepsilon}^{2}$, respectively.

Analyses of variance were performed with SAS (SAS, 2010 ) using a $95 \%$ confidence level. The effects of the water (factor A) and nitrogen (factor B) treatments, block differences (Block), interaction between the block and the water treatments $($ Block $\times A)$, and interaction between the water and nitrogen treatments $(\mathrm{A} \times \mathrm{B})$ were investigated.
The MIXED procedure in SAS was used to determine the random effect of block. When it was determined that blocks had no significant effect, the GLM procedure was used for the analysis of variance. The mean square of the strip-plot error, MS(StPE), was subtracted from the subplot error $\left(\mathrm{MSE}_{\mathrm{AB}}\right)$, which resulted in a smaller $\mathrm{MSE}_{\mathrm{AB}}$, and it was the error term used to test the $\mathrm{A} \times \mathrm{B}$ interaction. This gave improved precision in the tests for interaction effects (Steel and Torie, 1980).

\section{RESULTS AND DISCUSSION \\ Climatic Data}

The average air temperatures during the growing season (May to September) were $17.1^{\circ} \mathrm{C}$ in 2008 and $16.7^{\circ} \mathrm{C}$ in 2009 , which were similar to the 30 -year average $\left(17.0^{\circ} \mathrm{C}\right)$. The distribution of rainfall over the growing season was similar between the two years. The total precipitation for the growing season (May to September) was 432 and $462 \mathrm{~mm}$ in 2008 and 2009, respectively, compared to last 30 -year average rainfall of $474 \mathrm{~mm}$ during the same period.

\section{DRAINAGE AND SUbIRRIGATION}

The amount of water drained from the CD-SI plots was more than twice that of the conventionally drained plots in each block and each year (table 3 ). The greater volume of drainage water in the CD-SI plots was due to extra water supplied through subirrigation, which resulted in more water being stored in the soil profile and then released when the drainage valves were opened. The amount of water supplied through subirrigation is presented in table 3 . The amount of subirrigation water supplied was highest (34\% to $36 \%$ of 164 to $171 \mathrm{~mm}$ ) in the month of August for both years. Approximately, $64 \%$ to $68 \%$ of total subirrigation water was supplied in the two months of August and September in both 2008 and 2009 when the corn had reached the reproductive stage of growth (fig. 3 ).

\section{SoIL Moisture Storage}

Soil moisture values measured from 18 June to 27 September in 2008 and 2009 at two depths in the FD and CDSI plots are shown in figure 4. As observed, soil moisture was always higher in the CD-SI plots than the FD plots once subirrigation was started. The average moisture stored in the soil profile $(0$ to $100 \mathrm{~cm})$ in the FD plots was 161.1 and $127.9 \mathrm{~mm}$ in 2008 and 2009, respectively. Over the same period, the average soil moisture stored in the soil profile $(0$ to $60 \mathrm{~cm})$ in the CD-SI plots was 179.4 and $146.1 \mathrm{~mm}$ in 2008 and 2009, respectively. The difference in soil moisture storage for the two water treatments was $14 \%$ and $11 \%$ in 2008 and 2009, respectively.

Table 3. Total amount of drainage $(\mathrm{mm})$ and subirrigation $(\mathrm{mm})$ water measured during the growing season (May to September). ${ }^{[a]}$

\begin{tabular}{cccccc}
\hline & \multicolumn{2}{c}{ Drainage } & & \multicolumn{2}{c}{ Subirrigation } \\
\cline { 2 - 3 } \cline { 5 - 6 } Year & FD & CD-SI & & FD & CD-SI \\
\hline 2008 & 40.1 & 85.5 & & 0 & 164.3 \\
2009 & 27.6 & 58.2 & & 0 & 171.3 \\
\hline [a] & FD = free or conventional drainage; CD-SI = controlled drainage plots \\
\multicolumn{2}{l}{ with subirrigation. No subirrigation was applied to FD plots. }
\end{tabular}




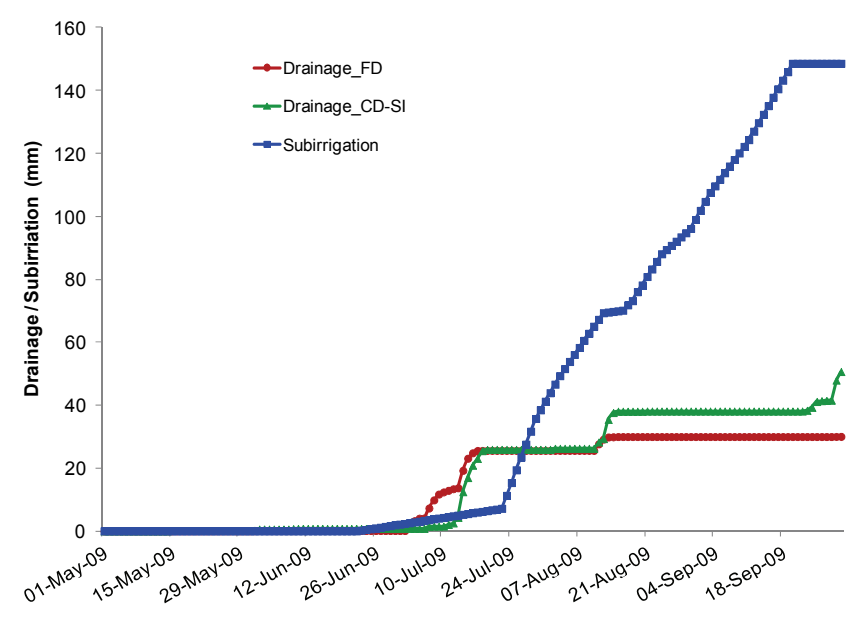

Figure 3. Cumulative drainage and total subirrigation water supplied in 2009 for FD and CD-SI plots (block A).

\section{WATER BALANCE}

The water balances $\left(I+P-\mathrm{ET}_{c}-D \pm \Delta S W+U F\right)$ for the two water treatments differed, as shown in figure 5 . The

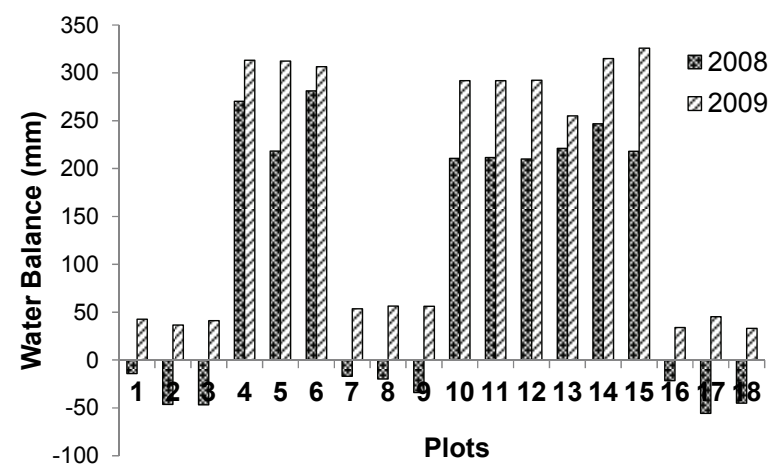

Figure 5. Water balance $\left(I+P-E_{c}-D \pm \Delta S W+U F\right)$ for all plots for conventional drainage (FD) and subirrigation (CD-SI) plots for 2008 and 2009. Numbers 1 to 3,7 to 9, and 16 to 18 are FD plots; numbers 4 to 6 and 10 to 15 (shaded areas) are CD-SI plots.

water balances in the FD and CD-SI treatments in 2008 and 2009 are also shown in table 4. Crop evapotranspiration $\left(\mathrm{ET}_{c}\right)$ exceeded precipitation for all months of the growing

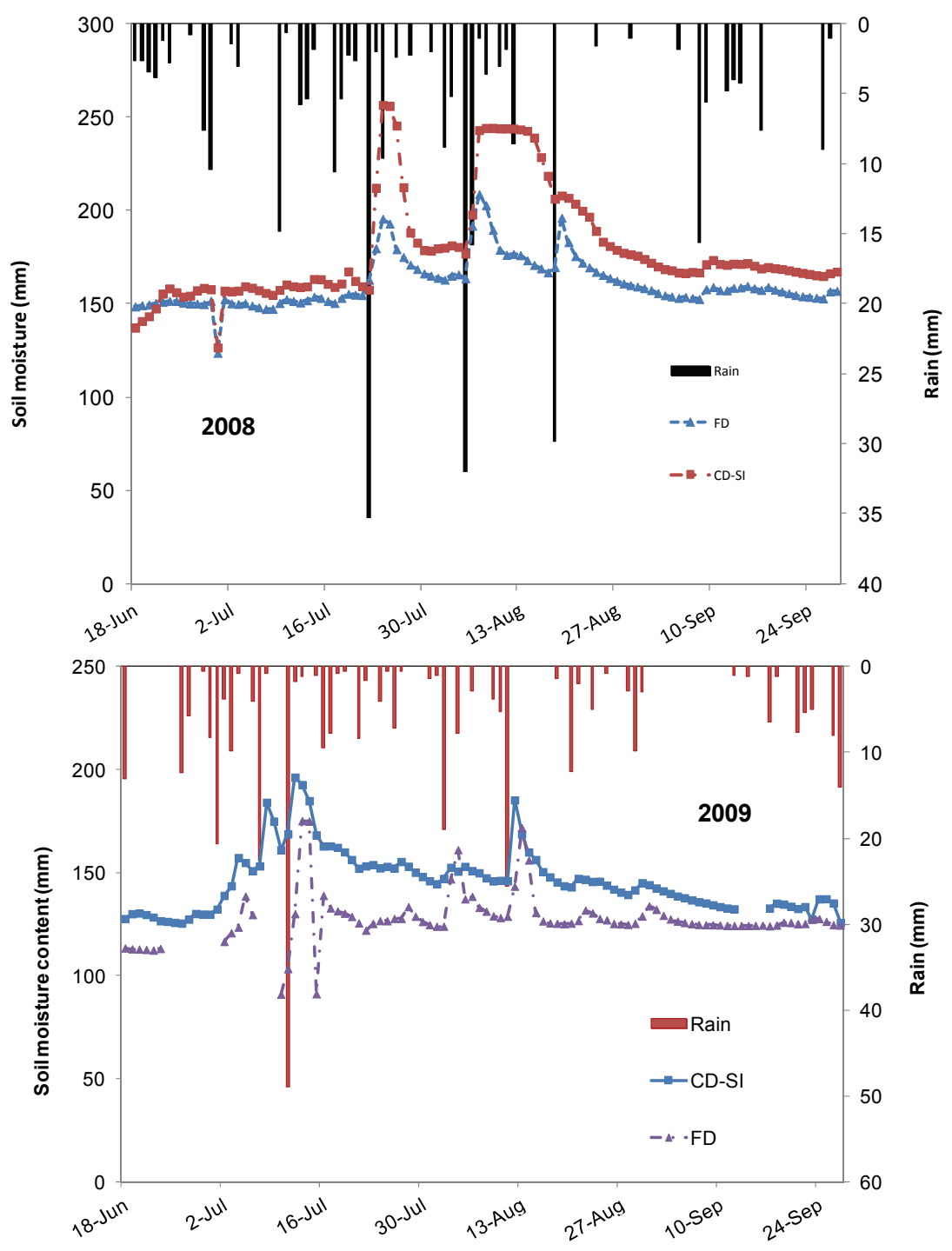

Figure 4. Variation is soil moisture storage in FD and CD-SI plots measured from 18 June to 30 September in 2008 and 2009. 
Table 4. Water balance $\left(I+P-E_{c}-D \pm \Delta S W+U F\right)$ for one plot each in the conventional drainage (FD) and subirrigation (CD-SI) treatments in 2008 and 2009 at the experimental site during the growing season. All units are in $\mathbf{m m}$.

\begin{tabular}{|c|c|c|c|c|c|c|c|c|}
\hline & Month & Rain & Irrigation & $\mathrm{ET}_{c}$ & Drainage & $\begin{array}{c}\text { Upward } \\
\text { Flux }\end{array}$ & $\begin{array}{c}\text { Soil Water } \\
\text { Storage }\end{array}$ & $\begin{array}{c}\text { Water } \\
\text { Balance }\end{array}$ \\
\hline \multirow[t]{5}{*}{ CD-SI plot 4 (2008) } & June $^{[\mathrm{a}]}$ & 35.2 & 21.0 & 48.6 & 0.0 & 20.5 & -3.9 & 24.3 \\
\hline & July & 107.1 & 35.3 & 143.7 & 34.1 & 61.9 & 12.0 & 38.6 \\
\hline & August & 112.2 & 52.0 & 135.3 & 10.3 & 65.1 & 44.9 & 128.5 \\
\hline & September & 56.6 & 46.7 & 49.5 & 16.7 & 37.6 & 4.4 & 79.0 \\
\hline & Total & 311.1 & 155.0 & 377.1 & 61.1 & 185.1 & 57.3 & 270.3 \\
\hline \multirow[t]{5}{*}{ FD plot 1 (2009) } & June $^{[a]}$ & 40.0 & 0.0 & 34.0 & 0.0 & 8.4 & 2.6 & 17.1 \\
\hline & July & 157.8 & 0.0 & 112.4 & 24.5 & 34.3 & -5.9 & 49.3 \\
\hline & August & 102.1 & 0.0 & 133.0 & 4.4 & 22.9 & 1.0 & -11.3 \\
\hline & September & 58.6 & 0.0 & 88.6 & 0.1 & 16.6 & 1.3 & -12.2 \\
\hline & Total & 358.5 & 0.0 & 367.9 & 28.9 & 82.2 & -1.0 & 42.9 \\
\hline
\end{tabular}

[a] Data from 18 to 30 June are included for the water balance because soil water storage data were available from 18 June.

season except September 2008 and July and September 2009 (table 4). In September, precipitation was greater than $\mathrm{ET}_{c}$ by $14 \%$ to $18 \%$. Rainfall was $20 \%$ and $10 \%$ less than the total crop water demand $\left(\mathrm{ET}_{c}\right)$ in 2008 and 2009 , respectively. The upward flux contributed $4 \%$ to $8 \%$ of the $\mathrm{ET}_{c}$ demand for conventional drainage plots, where the water table depth was low $(>1 \mathrm{~m})$ during the growing season, and up to $17 \%$ for the controlled drainage plots, where the water table depth was high (fig. 2). The water balances were found to be different $(p<0.05)$ between the CD-SI and FD plots. The CD-SI plots had a water surplus of over $200 \mathrm{~mm}$ in both 2008 and 2009, whereas there was a water deficit in the FD plots in 2008 and a water surplus of less than $50 \mathrm{~mm}$ in 2009 . The water deficit ranged from -14.1 to $-55.4 \mathrm{~mm}$ in the FD plots in 2008. These water deficits and water surpluses in the plots are the errors in closing the water balance. However, crop yields were not negatively impacted by either condition. The water surplus can be attributed to deep percolation, seepage, and surface runoff, which were assumed to be zero in the model. Seepage can occur if there is deep cracking, worm holes, and macropores in the soil. High water tables for extended periods of time during the growing season in the CD-SI plots might have led to significant deep seepage losses. In addition, irrigation water supplied to the CD-SI plots through the water table control chambers reacted slowly to the changing water table level due to the frequent precipitation.

After heavy rainfall events, water ponding was observed in the corn rows. This water either evaporated or infiltrated into the soil and may not have been properly accounted for in equation 2. Inaccuracies in soil moisture estimates could be due to the fact that the Watermark sensors measured soil moisture in units of $\mathrm{kPa}$, which was converted to volumet- ric moisture content using soil moisture retention curves. These curves were measured in the laboratory using pressure plates, which could have led to further errors.

\section{DRY GRAIN AND ABOVEGROUND DRY BIOMASS YIELDS}

Corn grain yields in the FD plots were higher than in the CD-SI plots by $2 \%$ and $8 \%$ in 2008 and 2009 , respectively. However, corn grain yields were not different $(p>0.05)$ for the FD and CD-SI treatments in 2008 (table 5). Precipitation and upward flux from the shallow water table of just over $1 \mathrm{~m}$ in the FD plots contributed sufficient moisture for corn growth. Furthermore, favorable weather conditions and the fact that producer had planted peas in 2007 might have contributed to good yields in 2008 compared to earlier study periods. The pea crop has beneficial effects on soil quality and soil structure.

Corn grain yields responded differently to the two water treatments at different nitrogen levels in 2009 (table 6). At low and high nitrogen levels, the two water treatments had significant effects $(p<0.05)$ on grain yields. The yields in the FD plots were higher than in the CD-SI plots by 1.84 and $0.49 \mathrm{Mg} \mathrm{ha}^{-1}$ for the low $\mathrm{N}$ and high $\mathrm{N}$ treatments, respectively. However, at the normal nitrogen level, grain yields did not respond to the two water treatments $(\mathrm{p}=$ 0.3177). This might have been due to minimal nitrogen stress at the normal nitrogen level of $180 \mathrm{~kg} \mathrm{ha}^{-1}$ and no water stress for the two treatments, since precipitation occurred every other day during the growing season.

The two water treatments had no effect $(\mathrm{p}>0.05)$ on aboveground dry biomass yields in both years (table 5). The biomass yield in the FD plots was higher than in the CD-SI plots by $7 \%$ and $9 \%$ in 2008 and 2009 , respectively. Subirrigation began 47 days after planting, approximately

Table 5. Statistical analysis of dry grain yields $\left(\mathrm{Mg} \mathrm{ha}^{-1}\right)$, aboveground dry biomass yields $\left(\mathrm{Mg} \mathrm{ha}^{-1}\right)$ and water use efficiency $\left(\mathrm{kg} \mathrm{m}^{-3}\right)$ determined using evapotranspiration $\left(\mathrm{WUE}_{\mathrm{ET}}\right)^{[\mathrm{la}]}$

\begin{tabular}{|c|c|c|c|c|c|c|c|c|}
\hline \multirow[b]{3}{*}{ Effect $^{[b]}$} & \multicolumn{4}{|c|}{ Yields } & \multicolumn{4}{|c|}{ Water Use Efficiency } \\
\hline & \multicolumn{2}{|c|}{2008} & \multicolumn{2}{|c|}{2009} & \multicolumn{2}{|c|}{2008} & \multicolumn{2}{|c|}{2009} \\
\hline & Grain & Biomass & Grain & Biomass & Grain & Biomass & Grain & Biomass \\
\hline Mean FD & 12.54 & 8.42 & 11.34 & 7.41 & 2.49 & 1.67 & 2.46 & 1.61 \\
\hline Mean CD-SI & 12.26 & 7.88 & 10.44 & 6.78 & 2.43 & 1.56 & 2.26 & 1.47 \\
\hline Water treatment & NS & NS & $0.0366^{*}$ & NS & NS & NS & $0.0392 *$ & NS \\
\hline Block & NS & NS & NS & NS & NS & NS & NS & NS \\
\hline Water treatment $\times \mathrm{N}$ treatment & NS & NS & $0.0055^{*}$ & NS & NS & NS & $0.0049 *$ & NS \\
\hline Block $\times$ Water treatment & NS & NS & NS & NS & NS & NS & NS & NS \\
\hline
\end{tabular}

[a] $\mathrm{NS}=$ non-significant at the $\alpha=0.05$ level; asterisk (*) indicate significance at the $\alpha=0.05$ level.

[b] $\mathrm{FD}=$ free or conventional drainage; $\mathrm{CD}-\mathrm{SI}=$ controlled drainage with subirrigation; Water treatment $=\mathrm{FD}$ and $\mathrm{CD}$-SI factors; Water treatment $\times \mathrm{N}$ treatment $=$ interaction between water and nitrogen treatments; Block $\times$ Water treatment $=$ interaction between block and water treatment. 
Table 6. Statistical analyses of simple effects of treatments for mean dry grain yields $\left(\mathrm{Mg} \mathrm{ha}^{-1}\right)$ and mean water use efficiency $\left(\mathrm{kg} \mathrm{m}^{-3}\right)$ in 2009. ${ }^{\text {[a] }}$

\begin{tabular}{cccccc}
\hline Nitrogen & \multicolumn{2}{c}{ Yield } & & \multicolumn{2}{c}{ WUE $_{\mathrm{ET}}$} \\
\cline { 2 - 3 } \cline { 5 - 6 } Level & FD & CD-SI & & FD & CD-SI \\
\hline Low N & $10.75^{*}$ & $8.91^{*}$ & & $2.33^{*}$ & $1.93^{*}$ \\
Normal N & 11.20 & 10.82 & & 2.43 & 2.35 \\
High N & $12.07^{*}$ & $11.58^{*}$ & & $2.62^{*}$ & $2.51^{*}$ \\
\hline
\end{tabular}

[a] $\mathrm{FD}=$ free or conventional drainage; $\mathrm{CD}-\mathrm{SI}=$ controlled drainage with subirrigation. Asterisks (*) indicate significance at the $\alpha=0.05$ level.

at the 9 to 10 leaf stage of plant growth. There was good precipitation (102 to $158 \mathrm{~mm}$ ) in the months of July and August, providing optimum conditions for plant biomass growth. Therefore, there was no significant difference in dry biomass yields for the two water treatments.

When yields from conventional drainage and subirrigation plots for other experimental years at this site were compared, higher yields were also reported in 1998 and 1999 for FD plots (Madramootoo et al., 2001). However, subirrigation plots had higher yields in 1993, 1994, 1995, 1996, 2001, and 2002. Table 7 summarizes the yield results for the two water management systems at the experimental site between 1993 and 2009. In the very wet year of 1998, grain yields from the free drainage plots were $25 \%$ higher than from the CD-SI plots. The yield benefits of the CD-SI plots are best observed in years when there was a substantial increase in grain yields over the FD plots (e.g., 36.2\% in 2001). An interesting situation is that of 2002, in which $63 \%$ of the total seasonal rainfall $(475 \mathrm{~mm})$ occurred in the months of May and June. August was very dry, with a monthly rainfall of only $25 \mathrm{~mm}$. CD-SI was able to supply supplemental water in August, which led to 33\% higher yield compared to FD plots. This illustrates the benefits of being able to overcome drought stress with CD-SI during critical stages of crop growth. It is therefore advantageous to have a CD-SI system in dry years, as higher yields are achieved (Madramootoo et al., 2007). The FD system is advantageous in wet years. However, the use of CD-SI and cropping system should be based not only on economic benefits but also on environment quality, as CD-SI also reduces nitrogen pollution in water bodies by $17 \%$ to $80 \%$ (Skaggs et al., 2010).

\section{Crop WATER USE EFFICIENCY}

The water use efficiency $\left(\mathrm{WUE}_{\mathrm{ET}}\right)$ of grain corn ranged from 2.3 to $2.5 \mathrm{~kg} \mathrm{~m}^{-3}$ (tables 5 and 6) and is comparable to a global range of 1.1 to $2.7 \mathrm{~kg} \mathrm{~m}^{-3}$ (Zwart and Bastiaanssen,
2004). For the FD plots, WUE $E_{\mathrm{ET}}$ was similar in both 2008 and 2009 for grain corn yield. The $\mathrm{WUE}_{\mathrm{ET}}$ was $7 \%$ higher in 2008 than in 2009 for the CD-SI plots. The WUE $\mathrm{ET}_{\mathrm{ET}}$ for biomass yield was only 6\% higher in 2008 than in 2009 for the CD-SI plots, while it was higher by only $4 \%$ for the FD plots in 2008. Corn has the highest WUE when compared to rice, wheat, or cotton (Zwart and Bastiaanssen, 2004). With increased competition for water, and sharing of water among interprovincial partners, which is already almost fully allocated in some Canadian provinces under drought conditions (Mehdi et al., 2006), WUE data will help in the selection of appropriate cropping systems for a changing climate.

The effect of water management on $\mathrm{WUE}_{\mathrm{ET}}$ of corn grain was significant $(\mathrm{p}<0.05)$ in 2009 but not in 2008 . The WUE $E_{\mathrm{ET}}$ was $11 \%$ higher for the FD treatments than for the CD-SI treatments in 2009 and only 5\% higher in 2008. Water management did not have a significant effect $(\mathrm{p}>$ 0.05 ) on $\mathrm{WUE}_{\mathrm{ET}}$ of the aboveground biomass of corn in either year. This is likely due to the fact that the rainfall distribution was uniform for both years, with an interquartile range of 2.8 and $3.8 \mathrm{~mm}$ in 2008 and 2009 , respectively.

There was an interaction $(\mathrm{p}=0.0267)$ between water management and nitrogen treatment in 2009. Table 6 shows that the effects of the two water treatments on WUE $\mathrm{ET}_{\mathrm{ET}}$ were different at different nitrogen levels. At low and high nitrogen levels (table 6), the two water treatments had effects ( $p$ $<0.05)$ on $\mathrm{WUE}_{\mathrm{ET}}$. The average $\mathrm{WUE}_{\mathrm{ET}}$ of the FD plots was $21 \%$ higher compared to the CD-SI plots at the low $\mathrm{N}$ level and $7 \%$ higher at the high $\mathrm{N}$ plots. However, as seen for grain yields, there was no effect of the two water treatments on $\mathrm{WUE}_{\mathrm{ET}}$ at the normal nitrogen level.

\section{SUbIRRIGATION WATER USE EFFICIENCY}

Subirrigation water use efficiency (SWUE) of corn was considerably higher than $\mathrm{WUE}_{\mathrm{ET}}$ when calculated based on evapotranspiration, and it varied from 5.01 to $7.33 \mathrm{~kg} \mathrm{~m}^{-3}$ (table 8). This is because while $\mathrm{WUE}_{\mathrm{ET}}$ is independent of water supplied either due to rain or irrigation, subirrigation water was supplied only when the water table depth was lower than $0.6 \mathrm{~m}$ below the soil surface. Our results are comparable with those of Stampfli and Madramootoo

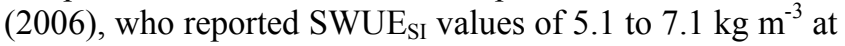
the same study site under reasonably similar conditions. $\mathrm{SWUE}_{\mathrm{TW}}$ ranged from 1.09 to $2.03 \mathrm{~kg} \mathrm{~m}^{-3}$ when precipitation was included in the subirrigation water supplied (ta-

Table 7. Comparisons of grain corn yields in FD and CD-SI scenarios.

\begin{tabular}{|c|c|c|c|c|c|c|}
\hline \multirow[b]{2}{*}{ Year } & \multirow{2}{*}{$\begin{array}{l}\text { Precipitation }^{[\mathrm{a}]} \\
(\mathrm{mm})\end{array}$} & \multicolumn{2}{|c|}{ Yield $\left(\mathrm{Mg} \mathrm{ha}^{-1}\right)^{[\mathrm{b}]}$} & \multirow{2}{*}{$\begin{array}{l}\text { Higher } \\
\text { Yield }\end{array}$} & \multirow{2}{*}{$\begin{array}{c}\text { Difference } \\
\text { in Yields }(\%)\end{array}$} & \multirow[b]{2}{*}{ References } \\
\hline & & FD & CD-SI & & & \\
\hline 1993 & 482.4 & 8.0 & 8.2 & CD-SI & 2.5 & \multirow{2}{*}{ Zhou et al. (2000) } \\
\hline 1994 & 443.9 & 8.9 & 9.4 & CD-SI & 5.6 & \\
\hline 1995 & 479.3 & 11.1 & 11.4 & CD-SI & 2.8 & \multirow{2}{*}{ Mejia et al. (2000) } \\
\hline 1996 & 500.9 & 6.8 & 7.3 & CD-SI & 6.9 & \\
\hline 1998 & 618.2 & 8.8 & 6.6 & FD & 25.0 & \multirow{2}{*}{ Madramootoo et al. (2001) } \\
\hline 1999 & 482.0 & 9.7 & 9.5 & FD & 1.7 & \\
\hline 2001 & 365.4 & 6.9 & 9.4 & CD-SI & 36.2 & \multirow{2}{*}{$\begin{array}{l}\text { Stampfli and Madramootoo } \\
(2006)\end{array}$} \\
\hline 2002 & 476.2 & 7.6 & 10.1 & CD-SI & 32.9 & \\
\hline 2008 & 431.9 & 12.5 & 12.3 & FD & 2.2 & \multirow{2}{*}{ This study } \\
\hline 2009 & 461.7 & 11.3 & 10.4 & FD & 8.0 & \\
\hline
\end{tabular}

[a] Precipitation from May to September; 30-year average precipitation of the growing season at the site was $474.4 \mathrm{~mm}$.

[b] $\mathrm{FD}=$ free or conventional drainage plots; $\mathrm{CD}-\mathrm{SI}=$ controlled drainage plots with subirrigation. 
Table 8. Water use efficiency $\left(\mathrm{kg} \mathrm{m}^{-3}\right)$ determined using volume of water supplied during the growing season.

\begin{tabular}{lcccccc}
\hline & & \multicolumn{2}{c}{ Mean } & & \multicolumn{2}{c}{ SD } \\
\cline { 3 - 4 } \cline { 6 - 7 } & Year & Grain & Biomass & & Grain & Biomass \\
\hline SWUE $\left._{\mathrm{TW}}{ }^{[\mathrm{a}]}\right]$ & 2008 & 2.03 & 1.31 & & 0.10 & 0.70 \\
& 2009 & 1.63 & 1.09 & & 0.20 & 0.16 \\
\hline SWUE $_{\mathrm{TSI}}{ }^{[\mathrm{b}]}$ & 2008 & -0.11 & -0.25 & & 0.54 & 0.60 \\
& 2008 & -0.11 & -0.25 & & 0.54 & 0.60 \\
\hline SWUE $_{\mathrm{SI}}{ }^{[\mathrm{c}]}$ & 2008 & 7.33 & 5.14 & & 0.59 & 0.26 \\
& 2009 & 5.09 & 3.50 & & 0.60 & 0.55 \\
\hline
\end{tabular}

[a] Subirrigation water use efficiency when precipitation was included with subirrigation water supplied.

[b] Subirrigation water use efficiency by difference in yields in FD and CD-SI plots, divided by total volume of subirrigation water supplied.

[c] Subirrigation water use efficiency when yields in subirrigation plots were divided by the total volume of subirrigation water supplied.

ble 8). It is important to note that when $\mathrm{SWUE}_{\mathrm{TSI}}$ was calculated using the difference in yields for the FD and CD-SI plots, in order to account for the effects of precipitation on yields in both water treatments, $\mathrm{SWUE}_{\mathrm{TSI}}$ was negative, indicating that subirrigation was not required in these particular years.

\section{CONCLUSiOnS}

This study compared the water balance, crop yield, and water use efficiency of FD and CD-SI plots at three nitrogen levels (low, normal, and high). The seasonal water balance showed surplus water conditions in the CD-SI plots, while the FD plots had deficit conditions. The deficit conditions in the FD plots might be due to deep percolation, seepage, surface runoff, and inaccuracies in soil moisture estimates. The surplus water conditions in the CD-SI plots were due to extra irrigation water supplied. The FD plots had higher yields than the CD-SI plots by 1.84 and $0.49 \mathrm{Mg} \mathrm{ha}^{-1}$ for the low and high $\mathrm{N}$ treatments, respectively. The biomass yield in the FD plots was higher than in the CD-SI plots by $7 \%$ and $9 \%$ in 2008 and 2009, respectively. The water use efficiency $\left(\mathrm{WUE}_{\mathrm{ET}}\right.$ ) of grain corn ranged from 2.3 to $2.5 \mathrm{~kg} \mathrm{~m}^{-3}$. The average $\mathrm{WUE}_{\mathrm{ET}}$ in the FD plots was found to be $21 \%$ higher than in the CD-SI plots for the low N level. Subirrigation water use efficiency $\left(\mathrm{SWUE}_{\mathrm{SI}}\right)$ ranged from 5.01 to $7.33 \mathrm{~kg}$ $\mathrm{m}^{-3}$ when only the volume of subirrigation water was used. However, when precipitation was included with the supplied subirrigation water, SWUE ranged from 1.09 to $2.03 \mathrm{~kg} \mathrm{~m}^{-3}$. Subirrigation did not improve the WUE of the CD-SI plots compared to the FD plots, as evident from the negative values of $\mathrm{SWUE}_{\mathrm{TSI}}$ during the period of study. For optimum crop yields, it is advantageous to have CD-SI systems in dry years and FD systems in wet years.

\section{ACKNOWLEDGEMENTS}

The authors thank the Natural Sciences and Engineering Research Council of Canada (NSERC) for providing funding for this project. We also thank Apurva Gollamudi, formerly of the Brace Center for Water Resources Management, McGill University, and Peter Kirby, Department of Natural Resource Sciences, McGill University, for their technical support. We are grateful to the reviewers whose constructive comments helped improve the manuscript.

\section{REFERENCES}

Allen, R. G., Pererira, L. S., Raes, D., \& Smith, M. (1998). Crop evapotranspiration: Guidelines for computing crop water requirements. FAO Irrigation and Drainage Paper 56. Rome, Italy: United Nations FAO.

Bos, M. G. (1980). Irrigation efficiencies at crop production level. ICID Bull, 29(2), 18-25, 60.

Brown, L. R. (2006). Plan B 2.0: Rescuing a Planet under Stress and a Civilization in Trouble. New York, N.Y.: W.W. Norton.

Busman, L., \& Sands, G. (2012). Agricultural drainage publication series: Issues and answers. St. Paul, Minn.: University of Minnesota Extension Service.

FAOSTAT. (2009). FAOSTAT website. Rome, Italy: United Nations FAO. Retrieved from http://faostat.fao.org/site/567/DesktopDefault.aspx?PageID=567 \#ancor.

Gollamudi, A. (2006). Hydrological and water quality modeling of agricultural fields in Quebec. MS thesis. Montreal, Quebec, Canada: McGill University, Department of Bioresource Engineering.

Hengeveld, H. G. (2000). Projections for Canada's climate future: A discussion of recent simulations with the Canadian global climate model. Climate change digest: Special edition CCD 0001. Ottawa, Ontario, Canada: Environment Canada.

Howell, T. A. (2001). Enhancing water use efficiency in irrigated agriculture. Agron. J., 93(2), 281-289. http://dx.doi.org/10.2134/agronj2001.932281x.

Hundal, S. S., Schwab, G. O., \& Taylor, G. S. (1976). Drainage system effects on physical properties of a lakebed clay soil. SSSA J., 40(2), 300-305. http://dx.doi.org/10.2136/sssaj1976.03615995004000020028x.

ICID. (2011). Country profile: Canada. International Commission on Irrigation and Drainage. Retrieved from www.icid.org/cp_canada.html.

Kaluli, J. W., Madramootoo, C. A., Zhou, X., Mackenzie, A. F., \& Smith, D. L. (1999). Subirrigation systems to minimize nitrate leaching. J. Irrig. Drain. Eng., 125(2), 52-58. http://dx.doi.org/10.1061/(ASCE)0733-9437(1999)125:2(52).

King, J. A. (1918). Tile Drainage. Mason City, Iowa: Mason City Brick \& Tile Co.

Lajoie, P., \& Stobbes, P. (1951). Étude des sols des comtés de Soulanges et de Vaudreuil dans la province de Québec. Ottawa, Ontario, Canada: Ministère Fédéral de l'Agriculture.

Madramootoo, C. A. (1990). Assessing drainage benefits on a heavy clay soil in Quebec. Trans. ASAE, 33(4), 1217-1223. http://dx.doi.org/10.13031/2013.31460.

Madramootoo, C. A., Wiyo, K. A., \& Enright, P. (1992). Nutrient losses through tile drains from two potato fields. Appl. Eng. Agric., 8(5), 639-646. http://dx.doi.org/10.13031/2013.26136.

Madramootoo, C. A., Dodds, G. T., \& Papadopoulos, A. (1993). Agronomic and environmental benefits of water table management. J. Irrig. Drain. Eng., 119(6), 1052-1065. http://dx.doi.org/10.1061/(ASCE)0733-9437(1993)119:6(1052).

Madramootoo, C. A., Helwig, T. G., \& Dodds, G. T. (2001). Managing water tables to improve drainage water quality in Quebec, Canada. Trans. ASAE, 44(6), 1511-1519.

Madramootoo, C. A., Johnston, W. R., Ayars, J. E., Evans, R. O., \& Fausey, N. R. (2007). Agricultural drainage management, quality, and disposal issues in North America. Irrig. and Drain., 56(S1), S35-S45. http://dx.doi.org/10.1002/ird.343.

Mehdi, B. B., Connollly-Boutin, B., \& Madramootoo, C. A. (2006). Coping with the impacts of climate change on water resources: A Canadian experience. World Resour. Rev., 18(1), 231-252.

Mejia, M. N., \& Madramootoo, C. A. (1998). Improved water quality through water table management in eastern Canada. $J$. Irrig. Drain. Eng., 124(2), 116-122. 
http://dx.doi.org/10.1061/(ASCE)0733-9437(1998)124:2(116).

Mejia, M. N., Madramootoo, C. A., \& Broughton, R. S. (2000).

Influence of water table management on corn and soybean yields. Agric. Water Mgmt., 46(1), 73-89. http://dx.doi.org/10.1016/S0378-3774(99)00109-2.

Montgomery, D. C. (2009). Design and Analysis of Experiments. New York, N.Y.: John Wiley and Sons.

Pablo, R. G., O’Neill, M. K., McCaslin, B. D., Remmenga, M. D., Keenan, J. G., \& Onken, B. M. (2007). Evaluation of corn grain yield and water use efficiency using subsurface drip irrigation. $J$. Sustain. Agric., 30(1), 153-172. http://dx.doi.org/10.1300/J064v30n01_10.

SAS. (2010). SAS/STAT User's Guide: Statistics. Ver 9.2. Cary, N.C.: SAS Institute, Inc.

Siebert, S., Döll, P., Feick, S., Hoogeveen, J., \& Frenken, K. (2007). The global map of irrigation areas. Frankfurt am Main, Germany: Johann Wolfgang Goethe University and United Nations FAO. Retrieved from www.unifrankfurt.de/45218039/Global_Irrigation_Map?.

Skaggs, R. (1977). Evaluation of water table control systems using a water management model. In Proc. 3rd Natl. Drain. Symp., 6168. St. Joseph, Mich.: ASAE.

Skaggs, R. W., Breve, M. A., Mohammad, A. T., Parsons, J. E., \& Gilliam, J. W. (1995). Simulation of drainage water quality with DRAINMOD. Irrig. Drain. Syst., 9(3), 259-277. http://dx.doi.org/10.1007/BF00880867.

Skaggs, R. W., Youssef, M. A., Gilliam, J. W., \& Evans, R. O. (2010). Effect of controlled drainage on water and nitrogen balances in drained lands. Trans. ASABE, 53(6), 1843-1850. http://dx.doi.org/10.13031/2013.35810.

Stampfli, N., \& Madramootoo, C. A. (2006). Water table management: A technology for achieving more crop per drop. Irrig. Drain. Syst., 20(1), 41-55.

Statistics Canada. (2011). Field crop reporting series. Catalogue No. 22-002-X, Table 001-0010. Ottawa, Ontario, Canada: Statistics Canada. Retrieved from www.statcan.gc.ca.

Steel, R. G. D., \& Torie, J. H. (1980). Principles and Procedures of Statistics: A Biometrical Approach. New York, N.Y.: McGraw Hill.

Tait, R. T., Madramootoo, C. A., \& Enright, P. (1995). An instrumented, field-scale research facility for drainage and water quality studies. Comput. Electron. Agric., 12(2), 131-145. http://dx.doi.org/10.1016/0168-1699(94)00043-P.

USGS. (2005). Irrigation water use. Reston, Va.: U.S. Geological Survey. Retrieved from http://ga.water.usgs.gov/edu/wuir.html.

Wright, J., \& Sands, G. (2001). Planning an agricultural subsurface drainage system. Publ. No. 07685. St. Paul, Minn.: University of Minnesota Extension Service. Retrieved from www.extension.umn.edu/distribution/cropsystems/DC7685.html.

Zhao, S. L., Gupta, S. C., Huggins, D. R., \& Moncrief, J. F. (2000). Predicting subsurface drainage, corn yield, and nitrate nitrogen losses with DRAINMOD-N. J. Environ. Qual., 29(3), 817-825. http://dx.doi.org/10.2134/jeq2000.00472425002900030018x.

Zhou, X., Madramootoo, C. A., MacKenzie, A. F., Kaluli, J. W., \& Smith, D. L. (2000). Corn yield and fertilizer N recovery in water-table-controlled corn-rye-grass systems. European $J$. Agron., 12(2), 83-92. http://dx.doi.org/10.1016/S11610301(99)00048-9.

Zwart, S. J., \& Bastiaanssen, W. G. M. (2004). Review of measured crop water productivity values for irrigated wheat, rice, cotton, and maize. Agric. Water Mgmt., 69(2), 115-133. http://dx.doi.org/10.1016/j.agwat.2004.04.007. 